\title{
TAMAN WISATA DAN KONSERVASI ANGGREK NUSANTARA
}

\author{
Odelia Clarissa $^{1)}$, Martin Halim ${ }^{2)}$ \\ 1) Program Studi S1 Arsitektur, Fakultas Teknik, Universitas Tarumanagara, odeliaclarissa@gmail.com \\ 2) Program Studi S1 Arsitektur, Fakultas Teknik, Universitas Tarumanagara, martinhalim90@gmail.com
}

\begin{abstract}
Abstrak
Bunga anggrek merupakan salah satu jenis bunga yang spesiesnya sangat banyak tumbuh alami di Indonesia. Sejarah perjalanan bunga anggrek di Indonesia sudah tercatat sejak tahun 1869 saat ditemukan di Borneo. Bunga anggrek sampai sekarang sangat popular di kalangan masyarakat Indonesia karena keanggunan dan keindahannya. Oleh karena itu, bunga anggrek memiliki daya tarik baik dari segi sejarah dan edukasi. Kawasan Sentra Anggrek dan Tanaman Hias di Kebon Jeruk, Jakarta Barat pernah menjadi salah satu pusat perdagangan dan budidaya anggrek. Namun, sudah beberapa tahun terakhir kawasan itu mulai dijadikan permukiman sehingga tidak ada lagi petani-petani anggrek yang membudidayakan dan menjual bunga anggrek. Bunga anggrek tidak hanya menarik bagi masyarakat Indonesia, namun juga internasional. Dengan daya tariknya kawasan Sentra Anggrek memiliki potensi untuk dijadikan area wisata di tengah kota. Dalam proyek Architourism of The Metropolis, diharapkan dapat ditemukan solusi yang dapat menghidupkan kembali kawasan Sentra Anggrek dan Tanaman Hias serta menjadikan kawasan tersebut sebagai tempat wisata yang dapat mengedukasi pengunjung serta mengembangkan budidaya anggrek sebagai salah satu bunga nasional Indonesia dengan dibangunnya taman indoor maupun outdoor yang dapat menjadi tempat habitat ex-situ bagi bunga anggrek Nusantara serta menyediakan ruang untuk mengembangkan teknologi pembibitan anggrek. Diharapkan dengan fasilitas-fasilitas yang dibangun dapat meningkatkan ketertarikan turis dan juga masyarakat akan bunga anggrek.
\end{abstract}

Kata kunci: Anggrek, Habitat Ex-Situ, Konservasi, Pembibitan Anggrek

\begin{abstract}
Orchid is a type of flower which species grow naturally in Indonesia. The history of orchid in Indonesia has been recorded since 1869 when it was found on Borneo. Orchid flowers are so popular among Indonesian people because of their elegance and beauty. That being said, orchids have an appeal both in terms of history and education. The Orchid and Ornamental Plants Center in Kebon Jeruk, West Jakarta, was once one of the centers for orchid trading and cultivation. However, in the last few years the area has been made into settlements so there are no more orchid farmers who cultivate and sell orchids. Orchid flowers are not only attractive to the people of Indonesia, but also internationally. With its attraction, the Sentra Anggrek area has the potential to become a tourism area in the middle of the big city. In the Architourism of The Metropolis project, it is expected to find a solution that can revive the Orchid and Ornamental Plants Center area and make the area a tourism place that can educate visitors and develop orchid cultivation as one of Indonesia's national interest with the construction of indoor and outdoor parks being a place for ex-situ habitat for Nusantara orchid flowers and providing space to develop orchid nursery technology. It is expected that the facilities built can increase the interest of tourists and also the people of orchid flower.
\end{abstract}

Keywords: Conservation, Ex-Situ Habitat, Orchid, Orchid Nursery

\section{PENDAHULUAN Latar Belakang}

Indonesia merupakan salah satu negara tropis yang memiliki jumlah spesies anggrek terbesar di dunia, yaitu sekitar 5.000 spesies dari total sekitar 30.000 spesies yang ada di 
dunia. Anggrek yang tumbuh alami di Indonesia tersebar di seluruh penjuru Nusantara. Karena keindahan dan keanekaragaman jenisnya, bunga anggrek sangat digemari oleh berbagai kalangan masyarakat. Mulai dari bunga anggrek yang mudah dibudidayakan hingga anggrek yang tergolong langka, sama-sama menarik perhatian masyarakat untuk membudidayakannya atau sekedar menjalankan hobi.

Sejak ditemukannya pada tahun 1869 di Borneo, bunga anggrek menjadi kegemaran di Indonesia oleh kalangan Belanda secara eksklusif. Barulah pada tahun 1930 masyarakat pribumi mulai membudidayakan bunga anggrek secara inklusif. Bahkan salah satu spesies bunga anggrek yaitu Anggrek Bulan di jadikan sebagai salah satu ikon bunga Indonesia, yaitu Puspa Pesona.

Budidaya bunga anggrek makin gencar dikembangkan mengingat potensi bunga anggrek terus meningkat. Lembaga penelitian dan nursery dalam negeripun telah mampu mengembangkan varietas-varietas baru yang mempunyai daya saing kuat dengan produk anggrek impor, selain teknologi budidaya yang semakin dikuasai, menjadikan harga jual anggrek mampu bersaing dengan produk impor. Berkembangnya usaha anggrek dalam negeri dapat meningkatkan banyak aspek, yaitu pendapatan petani anggrek, perluasan bidang biomedis dan obat herbal, industri pangan, hingga sektor pariwisata tropis. Menurut data Direktorat Tanaman Hias, sentra anggrek terbesar di Indonesia saat ini adalah di Pulau Jawa (Jawa Barat, DKI Jakarta, Jawa Tengah, Jawa Timur), Bali, Sumatera Utara, dan Sulawesi Selatan. Anggrek alami yang tumbuh secara endemik di Indonesia dapat menjadi daya tarik tersendiri terutama bagi sektor pariwisata.

Dalam tema Architourism of the Metropolis, pariwisata dengan bunga anggrek sebagai daya tariknya diharapkan dapat menjadi sebuah lokasi wisata yang bisa memberikan rasa dan pengalaman baru dan berbeda dari penatnya kota Jakarta dan memberi kesegaran bagi pengunjungnya.

\section{KAJIAN LITERATUR}

Walaupun tidak ada definisi jelas, istilah "tourism architecture" menjelaskan berbagai macam fungsi arsitektur dalam konteks pariwisata. Acierno (2005) kemudian menyebutnya "architecture of attractions". Architectural tourism tidak dibatasi kedalam periode waktu tertentu atau gaya arsitektur. Dalam arti yang lebih luas, istilah ini meliputi segala jenis pariwisata yang berdedikasi kepada arsitektur dan dapat dirasakan sebagai monument bersejarah hingga struktur kontemporer.

Dilain hal, istilah "architourism" untuk arsitektur kontemporer sebagai atraksi, diciptakan dalam sebuah konferensi pada 2002. P. L Pearce (1991) menjelaskan atraksi sebagai "sebuah situs bernama dengan fitur spesifik manusia atau alami, yang mana menjadi fokus pengunjung dan perhatian manajemen.

Bunga anggrek dibagi menjadi 3 jenis, yaitu bunga anggrek beriklim dingin, beriklim sedang dan beriklim panas. Bunga anggrek dapat tumbuh dengan baik dengan tingkat kelembapan sekitar $60 \%-80 \%$.

Tabel 1. Data anggrek berdasarkan iklim

\begin{tabular}{|c|c|c|}
\hline \multirow{2}{*}{ Iklim } & \multicolumn{2}{|c|}{ Suhu } \\
\cline { 2 - 3 } & Malam & Siang \\
\hline Dingin & $10^{\circ}-15^{\circ} \mathrm{C}$ & $15^{\circ}-21^{\circ} \mathrm{C}$ \\
\hline Sedang & $15^{\circ}-18^{\circ} \mathrm{C}$ & $21^{\circ}-32^{\circ} \mathrm{C}$ \\
\hline Panas & $18^{\circ}-24^{\circ} \mathrm{C}$ & $26^{\circ}-35^{\circ} \mathrm{C}$ \\
\hline
\end{tabular}

Sumber: www.aos.org 
Berdasarkan cara hidupnya, Bunga anggrek dibagi menjadi 2: hidup menempel pada inangnya (dapat di kulit pohon, di sela-sela tebing batu) dan juga dapat langsung ditanam di tanah. Anggrek yang membutuhkan inang disebut angrek epifit dan samasekali tidak merugikan pohon yang ditempel. Sedangkan bunga anggrek yang tumbuh langsung di tanah disebut anggrek terrestrial.

Tabel 2. Data anggrek berdasarkan cara hidup

\begin{tabular}{cl}
\hline Jenis Anggrek & \multicolumn{1}{c}{ Cara dan Tempat Hidup } \\
\hline \multirow{2}{*}{ Epifit } & $\begin{array}{l}\text { Menempel pada inang. Contoh: } \\
\text { Kulit/batang pohon, sela-sela } \\
\text { tebing batu. }\end{array}$ \\
\hline \multirow{3}{*}{ Terestrial } & $\begin{array}{l}\text { Tumbuh langsung di tanah. } \\
\text { Contoh: pot tanaman, tanah } \\
\text { langsung. }\end{array}$ \\
\hline
\end{tabular}

Sumber: www.aos.org

Bunga anggrek tidak dapat hidup di daerah yang terlalu basah atau terguyur air secara terus menerus. Hal itu dapat menyebabkan pembusukan pada umbi dan akarnya. Hal ini dapat dipermudah dengan menanam anggrek di dalam ruangan (indoor) sehingga pemberian air dapat lebih mudah dikendalikan.

Selain iklim dan cara hidup, anggrek sangat bergantung pada intensitas dan lama cahaya matahari yang diberikan. Berdasarkan kebutuhan cahayanya, anggrek dapat dibagi menjadi 5 jenis. Satuan yang umum dan menjadi patokan dalam konteks ini adalah fc (foot candle) dimana parameternya adalah cahaya 1 lilin (candle) dalam jarak 1 kaki (foot). 1 fc sama dengan 10.76 lux.

Tabel 3. Data anggrek berdasarkan kebutuhan cahaya

\begin{tabular}{lcl}
\hline \multicolumn{1}{c}{$\begin{array}{c}\text { Kebutuhan } \\
\text { cahaya }\end{array}$} & Intensitas & \multicolumn{1}{c}{ Keterangan } \\
\hline $\begin{array}{l}\text { Cahaya Terang } \\
\text { Sekali }\end{array}$ & $\pm 5000 \mathrm{fc}$ & $\begin{array}{l}\text { Cahaya matahari tanpa terhalang } \\
\text { selama 6 jam atau sepanjang hari } \\
\text { dibawah langit berawan }\end{array}$ \\
\hline Cahaya Terang & $\pm 3000-5000 \mathrm{fc}$ & $\begin{array}{l}\text { Cahaya matahari tanpa terhalang } \\
\text { selama 4-6 jam atau 50\%-70\% } \\
\text { dibawah shade }\end{array}$ \\
\hline Cahaya Sedang & $\pm 2000-3000 \mathrm{fc}$ & $\begin{array}{l}\text { Cahaya matahari langsung tanpa } \\
\text { terhalang selama 4 jam atau sinar } \\
\text { matahari tidak langsung } \\
\text { sepanjang hari atau 70\% - 80\% } \\
\text { dibawah shade }\end{array}$ \\
\hline Cahaya Teduh & $\pm 1000-2000 \mathrm{fc}$ & $\begin{array}{l}\text { Cahaya matahari selama 1-2 jam } \\
\text { atau 80\% - 90\% dibawah shade }\end{array}$ \\
\hline $\begin{array}{l}\text { Cahaya Sangat } \\
\text { Teduh }\end{array}$ & $\pm 1000-1500 \mathrm{fc}$ & $\begin{array}{l}\text { Cahaya matahari selama 1 jam } \\
\text { atau 90\% dibawah shade }\end{array}$ \\
\hline
\end{tabular}

Sumber: www.aos.org

\section{METODE}

Metode yang digunakan adalah metode pengumpulan data melalui studi literatur sebagai dasar pedoman dalam pengertian mengenai tema Architourism of the Metropolis serta melakukan pengamatan dan pengumpulan data dengan melakukan wawancara dan survei di kawasan Sentra Budidaya Anggrek dan Tanaman Hias di Kebon Jeruk. Setelah data literatur 
dan data lapangan didapatkan baru diterapkan pendekatan Architourism of the Metropolis di area tapak.

\section{DISKUSI DAN HASIL}

Tujuan utama dalam dilakukannya perancangan ini adalah untuk menghidupkan kembali Kawasan Sentra Anggrek dan Tanaman Hias seperti sediakala dengan berbagai macam tambahan fungsi yang mendukung sebagai area wisata, juga memberikan tempat yang layak kepada pedagang dan petani anggrek seperti layaknya sebuah sentra anggrek.

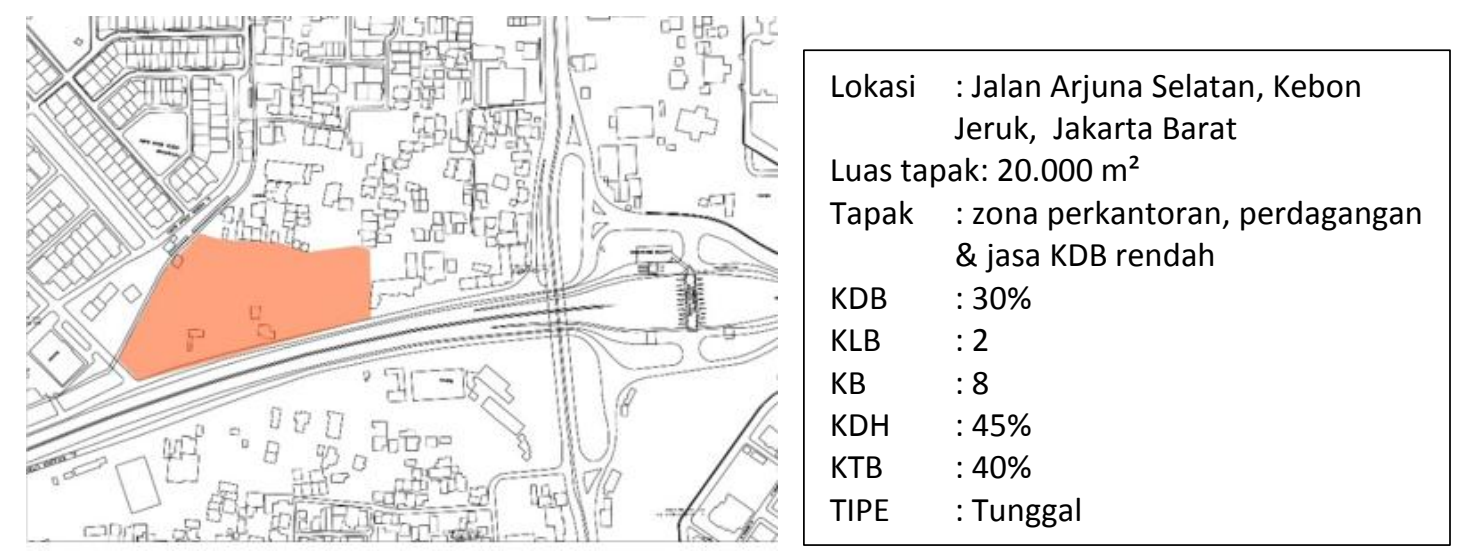

Gambar 1. Taman Virtual dalam taman indoor Sumber: dokumen pribadi, 2018

Dari data dan hasil analisis yang diperoleh dapat dilihat apa saja ketentuan-ketentuan perancangan yang mendasari proyek ini:

- Habitat anggrek dibuat berdasarkan kebutuhan cahaya matahari, suhu, dan ruang

- Memberikan sarana pengetahuan baik untuk anak-anak maupun dewasa

- Memberikan fasilitas untuk mengembangkan teknologi pembibitan anggrek

- Memberikan sarana bagi para pedagang dan petani anggrek untuk menjajakan dan membudidayakan bunga anggrek

- Penataan sirkulasi pengunjung agar mempermudah dalam memberikan edukasi dan pengalaman berjalan-jalan di taman

- Memberikan ruang untuk berbagi ilmu seputar anggrek

Berdasarkan studi Architourism Of The Metropolis, hasil analisis data dan ketentuanketentuan perencenaan proyek terhadap zona tapak dan massa bangunan diperoleh desain perancangan proyek sebagai berikut :

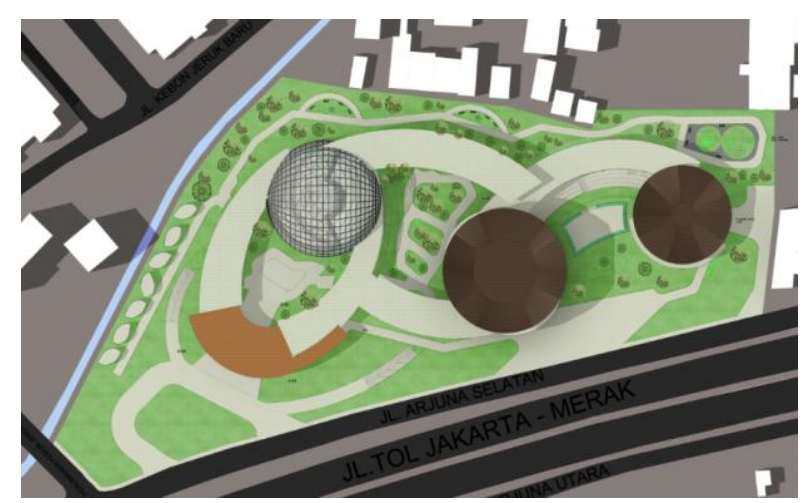

Gambar 2. Block plan

Sumber: dokumen pribadi, 2018 


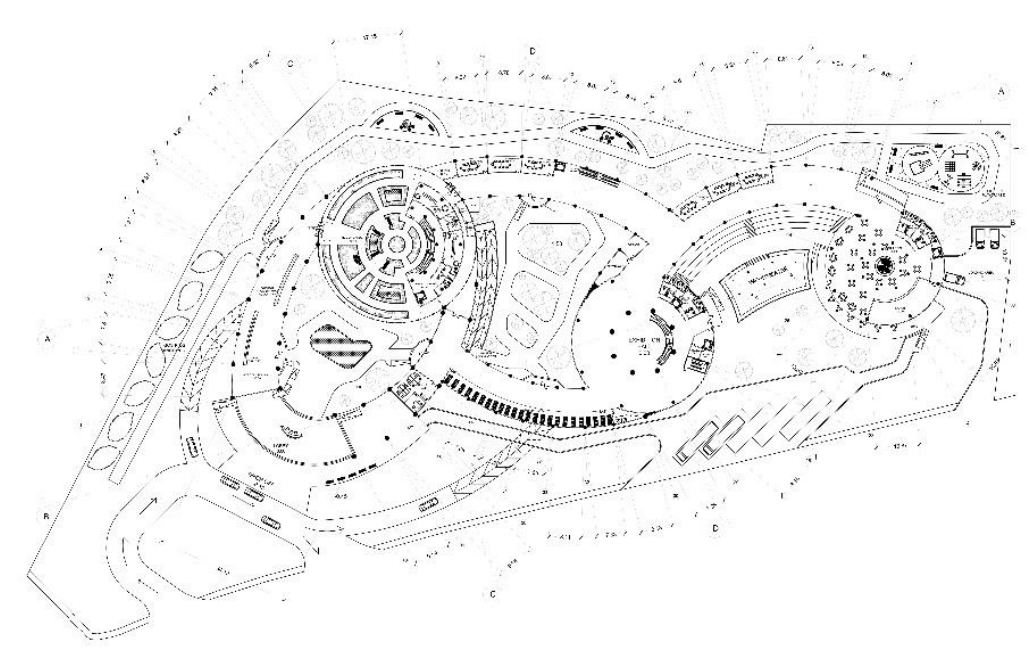

Gambar 3. Denah lantai dasar

Sumber: dokumen pribadi, 2018

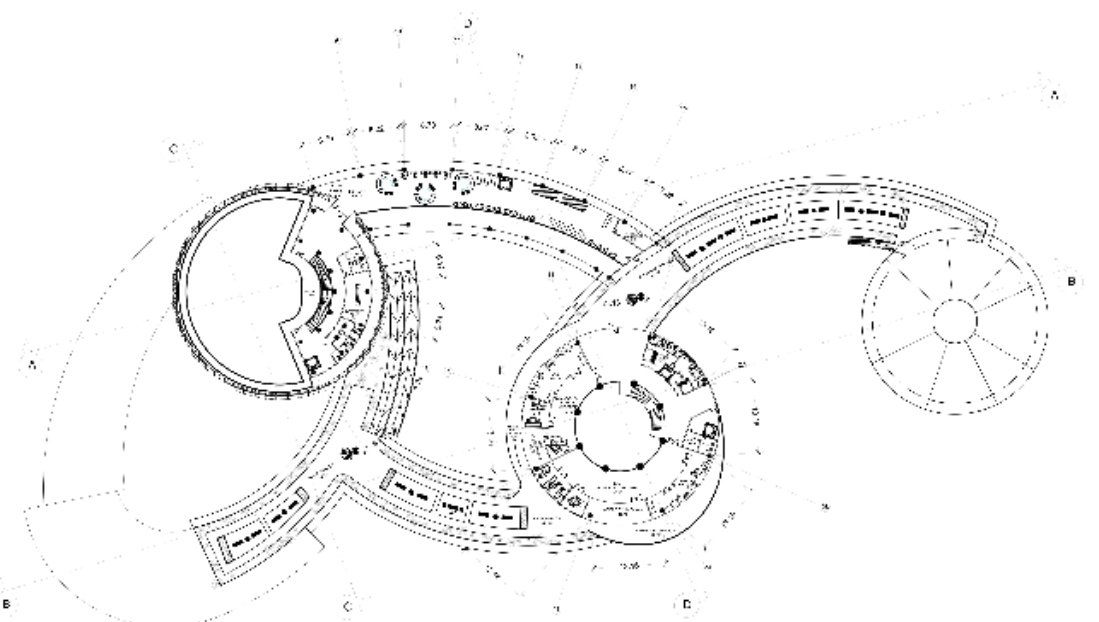

Gambar 4. Denah lantai 2

Sumber: dokumen pribadi, 2018

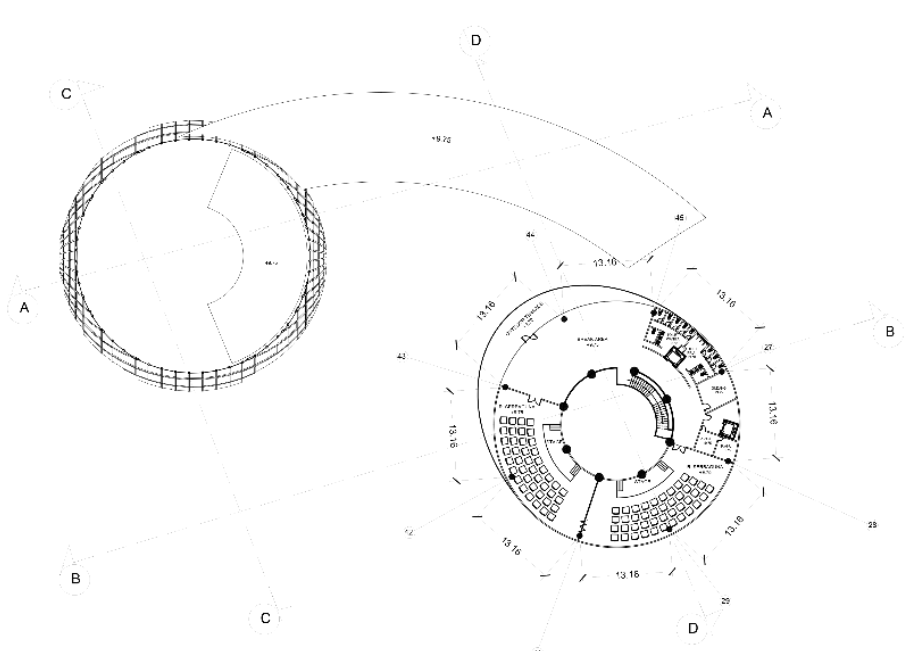

Gambar 5. Denah lantai 3

Sumber: dokumen pribadi, 2018 

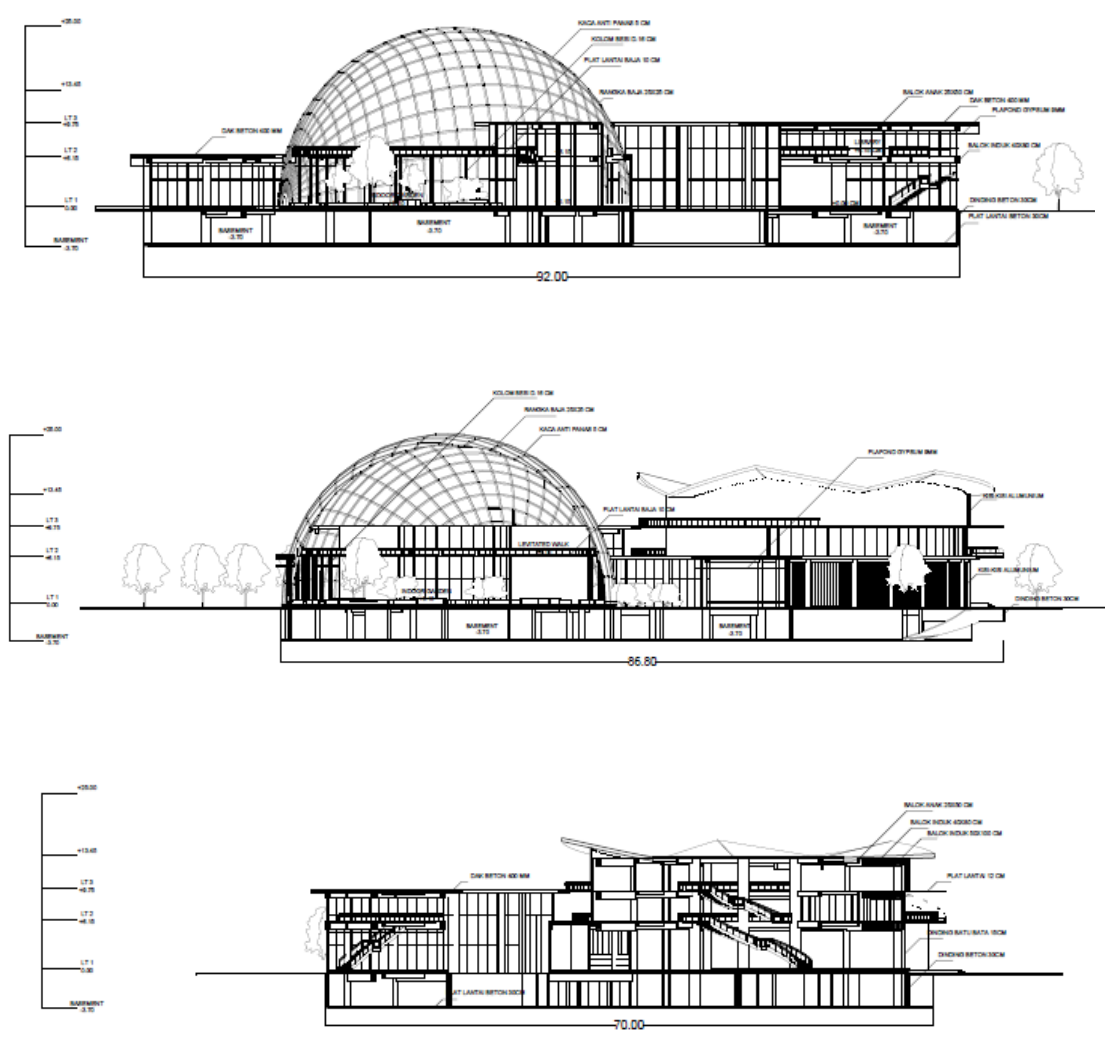

Gambar 6. Potongan A-A, C-C, D-D

Sumber: dokumen pribadi, 2018

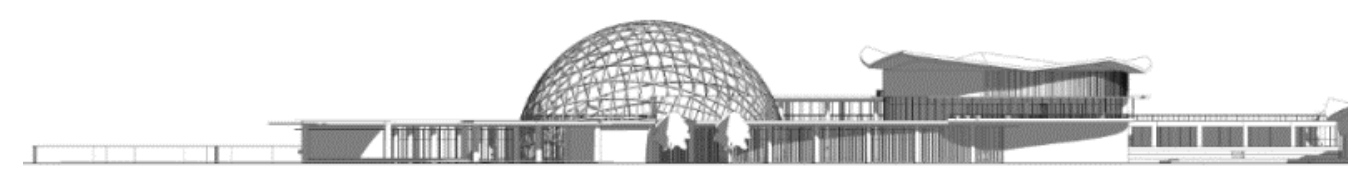

Gambar 7. Tampak depan

Sumber: dokumen pribadi, 2018

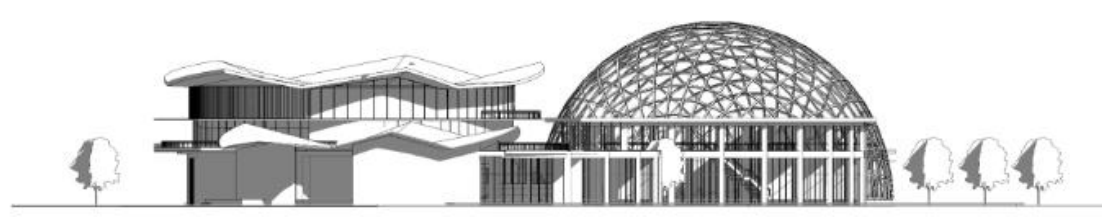

Gambar 8. Tampak Kanan

Sumber: dokumen pribadi, 2018

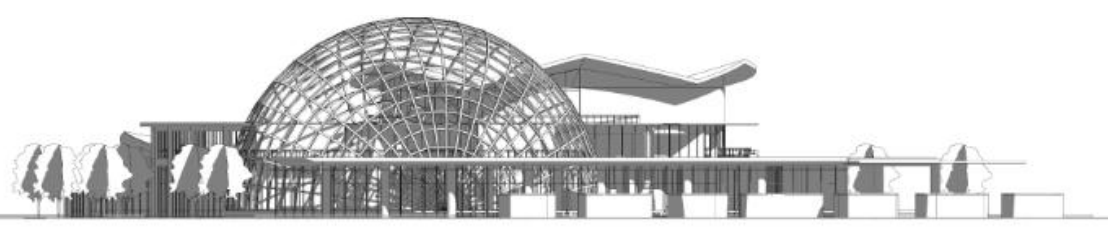

Gambar 9. Tampak Kiri

Sumber: dokumen pribadi, 2018 


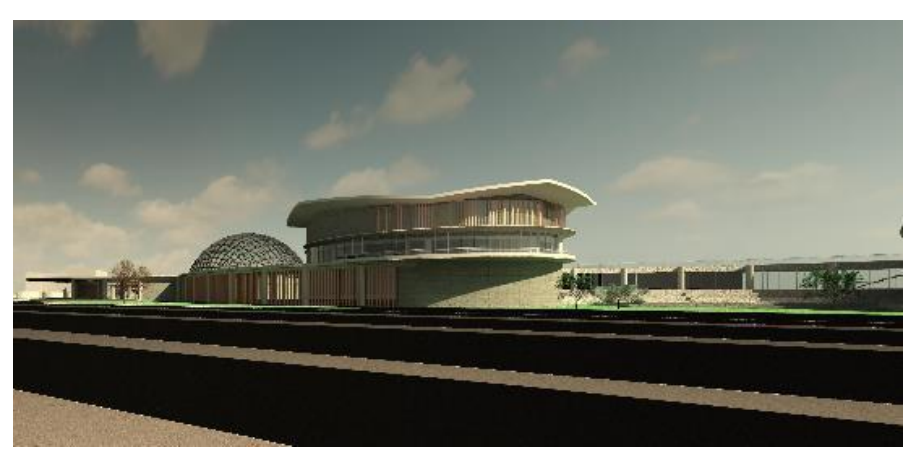

Gambar 10. Eksterior 1

Sumber: dokumen pribadi, 2018

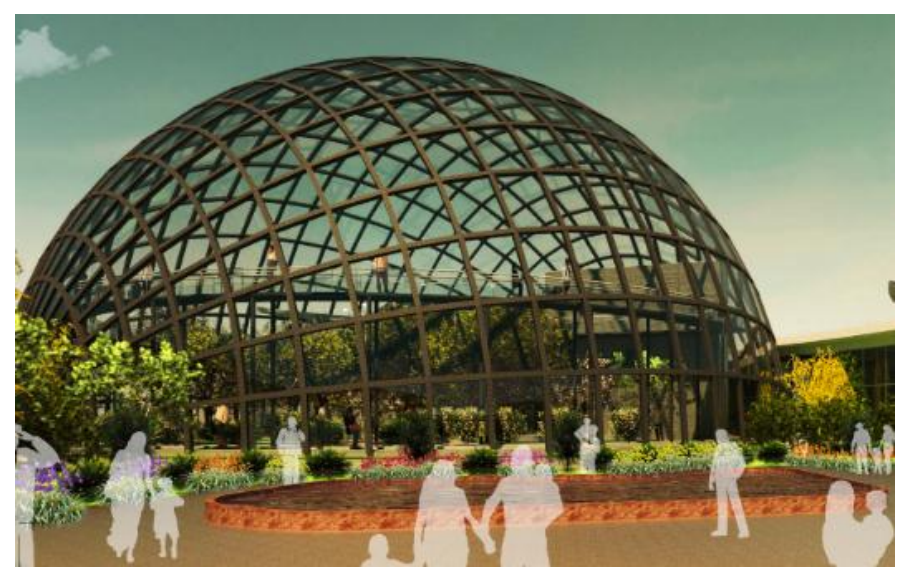

Gambar 11. Eksterior 2

Sumber: dokumen pribadi, 2018

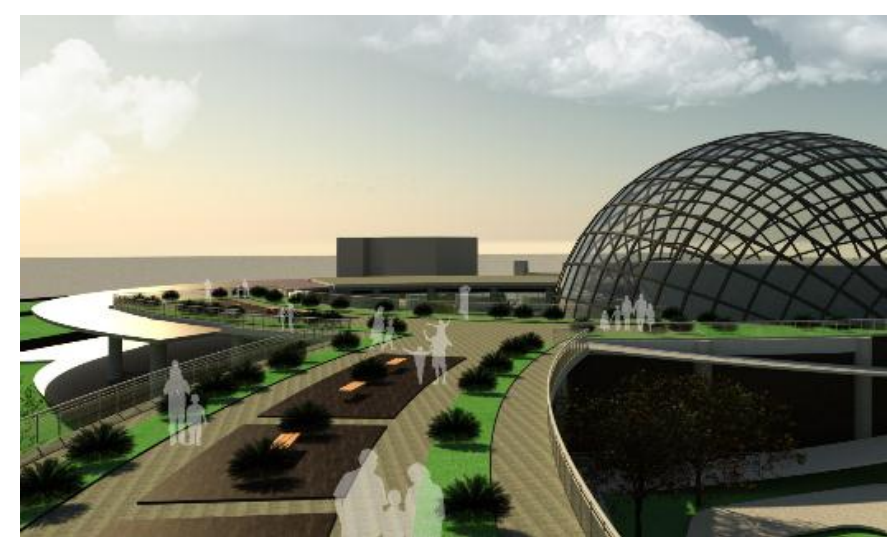

Gambar 12. Eksterior 3

Sumber: dokumen pribadi, 2018

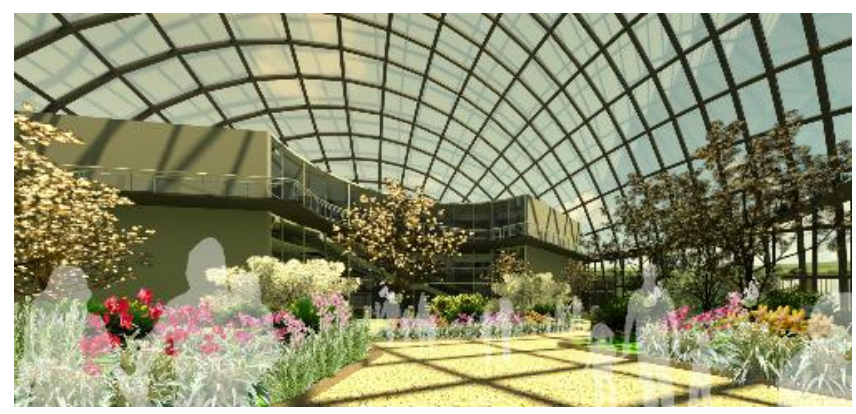

Gambar 13. Interior dome taman indoor Sumber: dokumen pribadi, 2018 


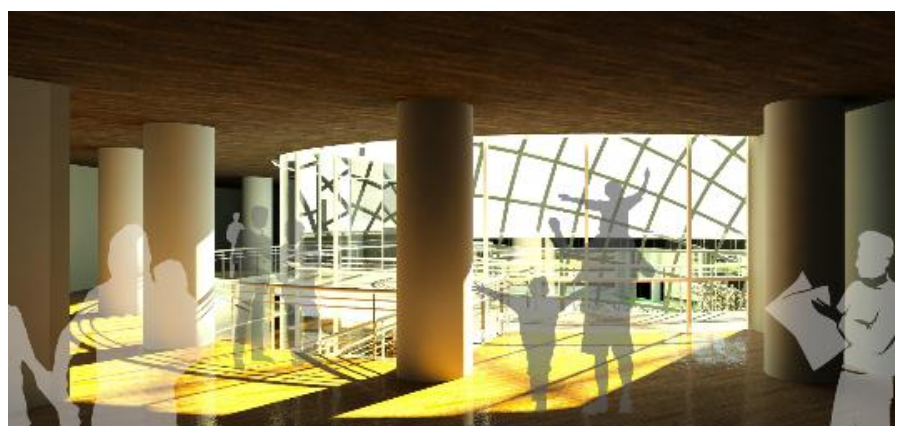

Gambar 14. Interior selasar taman virtual

Sumber: dokumen pribadi, 2018

\section{Taman Indoor, Outdoor, Virtual}

Dengan data kebutuhan bunga anggrek, maka dibangun habitan yang sesuai dengan kebutuhan masing-masing spesies. Taman indoor dikhususkan untuk bunga anggrek yang hidup di habitat dengan suhu dingin. Pembuatan taman indoor bertujuan untuk mempermudah pengaturan suhu ruangan agar cocok bagi spesies bunga anggrek yang ditanam didalamnya. Taman indoor berupa dome yang dilapisi kaca tahan panas dengan rangka baja.

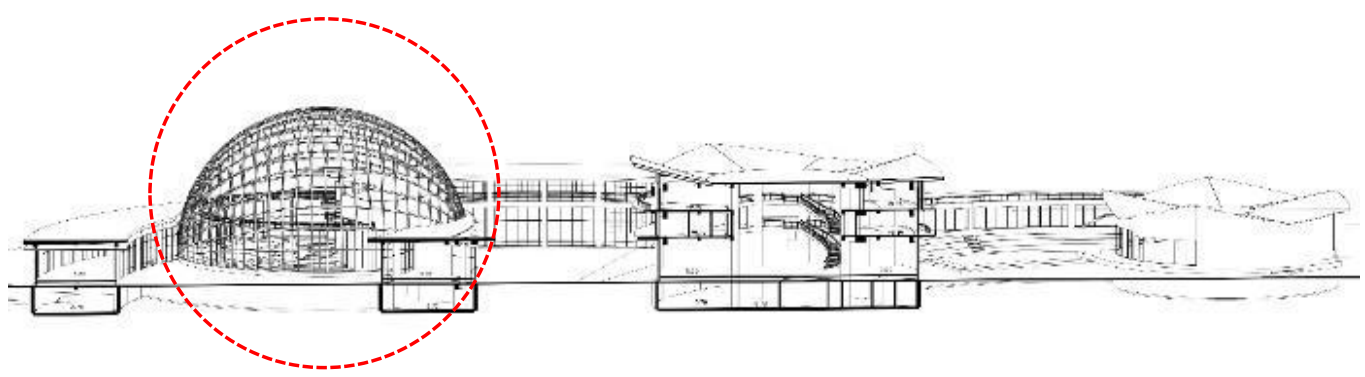

Gambar 15. Dome Taman Indoor

Sumber: dokumen pribadi, 2018

Taman virtual dikhususkan untuk menampilkan bunga anggrek yang tidak bisa ditanam di habitat ex-situ dengan teknologi hologram, komputer touch screen, dan scent station yang dapat memberikan semprotan wangi-wangian anggrek. Taman virtual ini berada di dalam dome dan memberikan akses ke levitation walk dimana pengunjung dapat berjalan di atas jembatan setinggi 5 meter dan melihat isi dome secara keseluruhan.

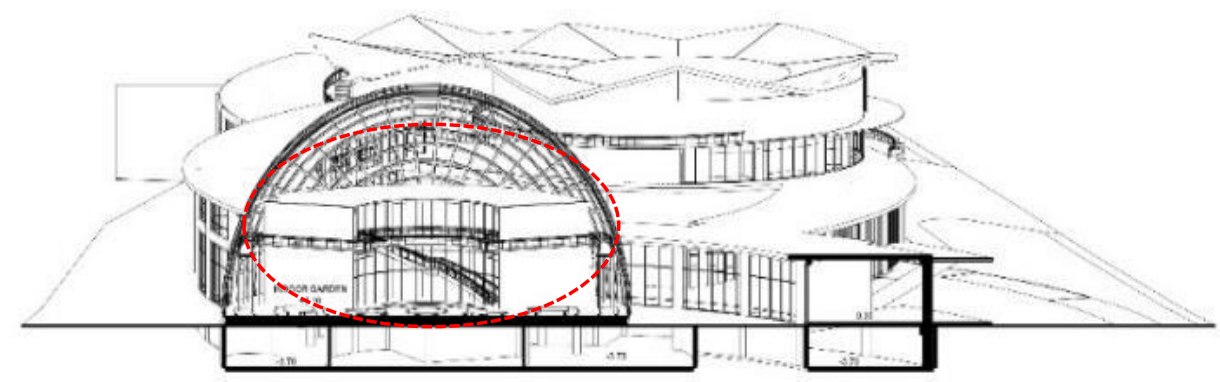

Gambar 16. Taman Virtual dalam taman indoor Sumber: dokumen pribadi, 2018 


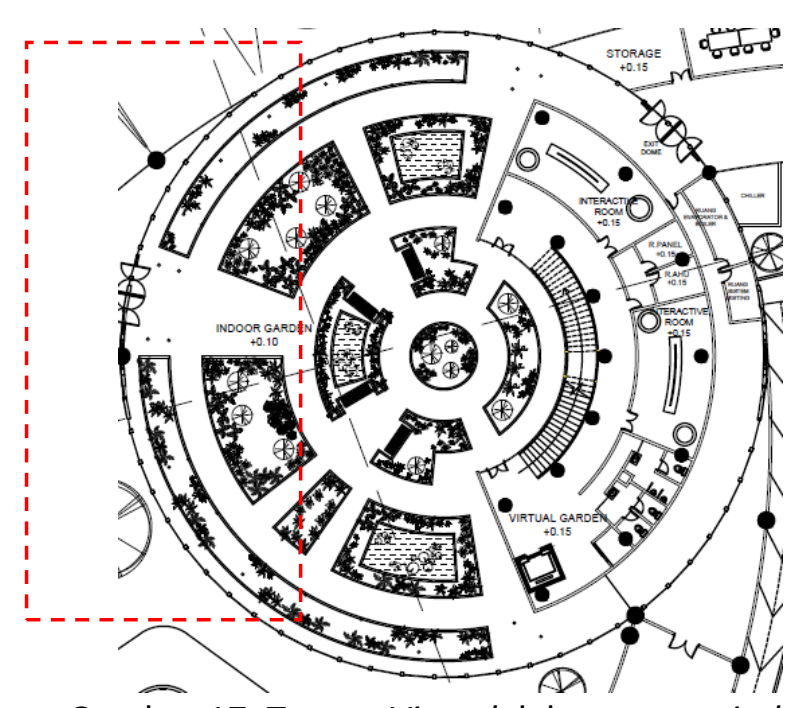

Gambar 17. Taman Virtual dalam taman indoor Sumber: dokumen pribadi, 2018

Taman outdoor menampung anggrek-anggrek yang memiliki kebutuhan suhu panassedang dan sinar matahari yang cukup. Taman outdoor mengelilingi bangunan dan para pengunjung dapat berjalan-jalan santai menikmati keindahan bunga anggrek.

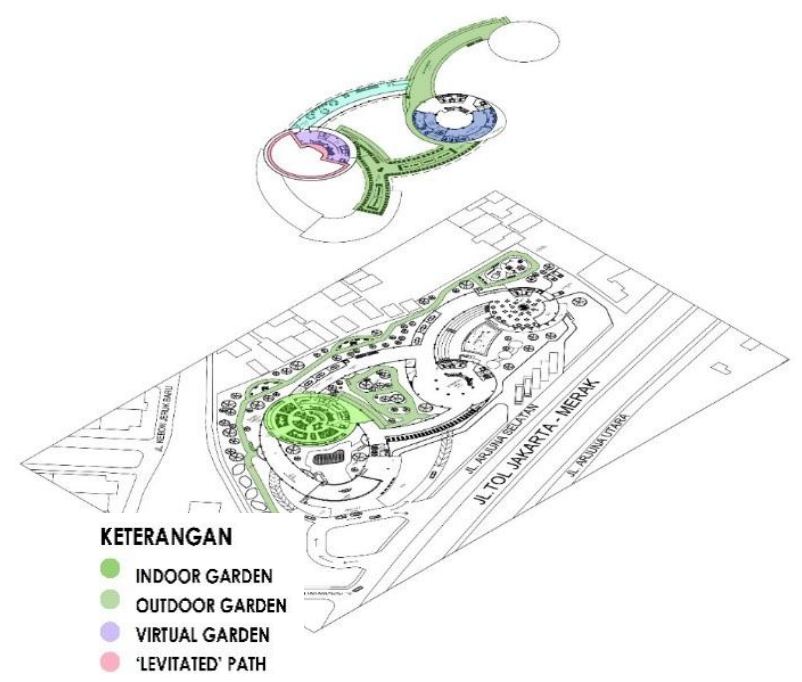

Gambar 18. Area Taman Indoor, Taman Virtual, Taman Outdoor Sumber: dokumen pribadi, 2018

Salah satu tujuan utama dalam proyek ini adalah mengedukasi pengunjung tentang anggrek, maka diberikan sarana-sarana seperti area workshop, perpustakaan, dan tour laboratorium pembibitan dan pengolahan anggrek.

Area workshop terletak di bagian penghubung antar bangunan. Tujuannya adalah saat para pengunjung berjalan melewati area tersebut, mereka akan tertarik melihat kegiatan pembelajaran di dalam ruangan kaca (dapat dilihat dari luar), dan mereka akan mendaftarkan diri untuk ikut serta dalam kegiatan tersebut. 


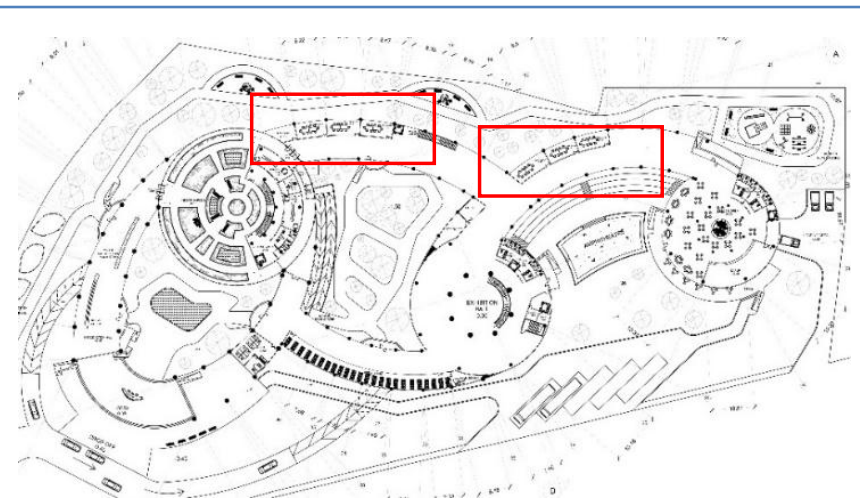

Gambar 19. Area workshop

Sumber: dokumen pribadi, 2018

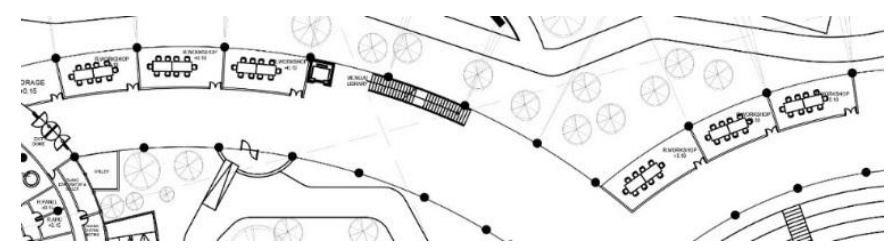

Gambar 20. Area workshop

Sumber: dokumen pribadi, 2018

Perpustakaan terletak di lantai 2. Perpustakaan ini menggunakan teknologi computer interaktif sehingga anak-anak maupun dewasa lebih tertarik dalam menggunakan fasilitas perpustakaan dan ilmu yang didapat lebih variatif dan mudah.

Perpustakaan dapat diakses dari 3 titik, yaitu dari taman virtual, tangga dari lantai 1, dan roof garden di lantai 2.

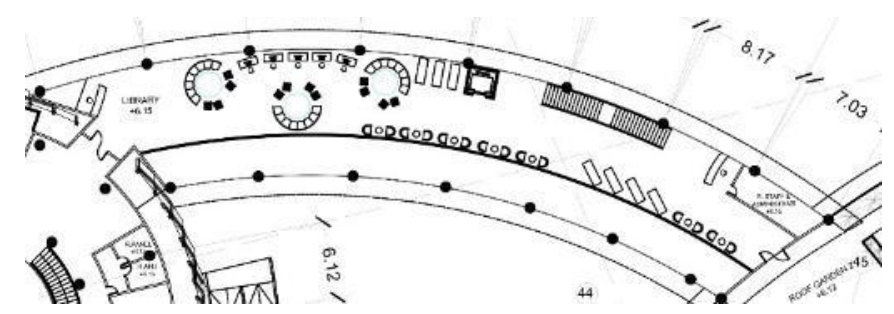

Gambar 21. Perpustakaan

Sumber: dokumen pribadi, 2018

\section{Laboratorium}

Terdapat 2 Laboratorium, yaitu laboratorium pembibitan anggrek dan laboratorium pengolahan anggrek. Laboratorium pembibitan anggrek terfokus dalam meningkatkan kualitas bunga anggrek yang dibudidayakan sehingga produk yang dihasilkan memiliki kualitas tinggi. Sedangkan laboratorium pengolahan anggrek berfungsi untuk mengolah hasil-hasil bunga anggrek dan menjadikan sebuah produk baru berasal dari anggrek. Hal ini memberikan insight bagaimana bunga anggrek tidak hanya sebagai hiasan atau koleksi saja, namun dapat dimanfaatkan untuk kepentingan budidaya dan komersial. 


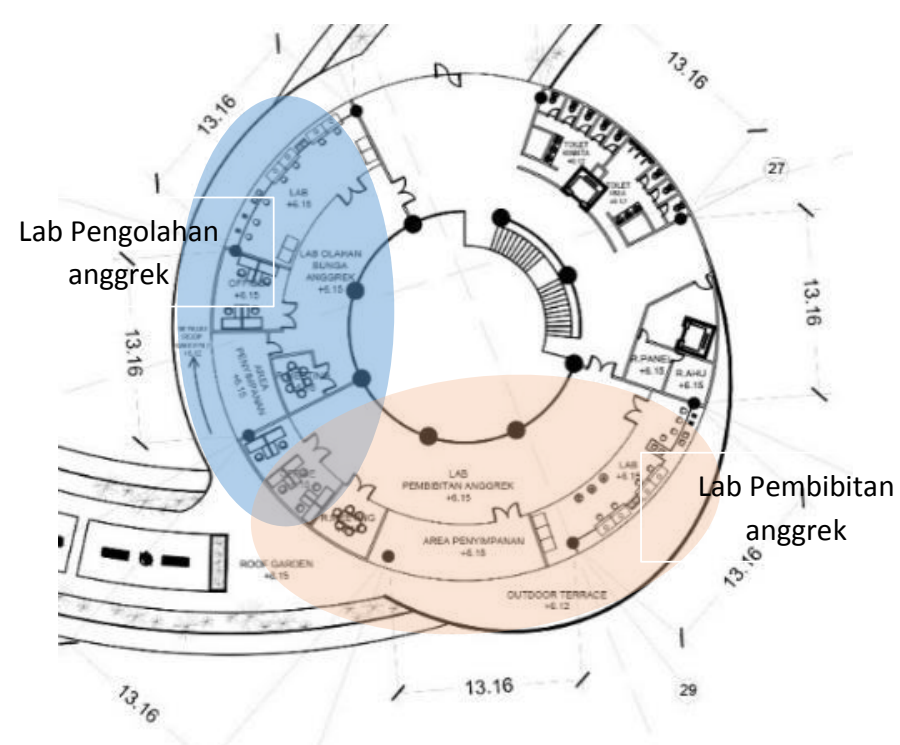

Gambar 22. Laboratorium

Sumber: dokumen pribadi, 2018

Terdapat communal space atau tempat berkumpul bagi para pengunjung yang ingin beristirahat. Terdapat 2 area berkumpul, di restoran dan di amphitheater yang terletak di sebelah restoran. Dengan adanya amphitheater, pengunjung dapat beristirahat sambil menikmati taman dan live music yang terjadwal. Pengunjung dapat melakukan piknik di taman sekitar amphitheater.

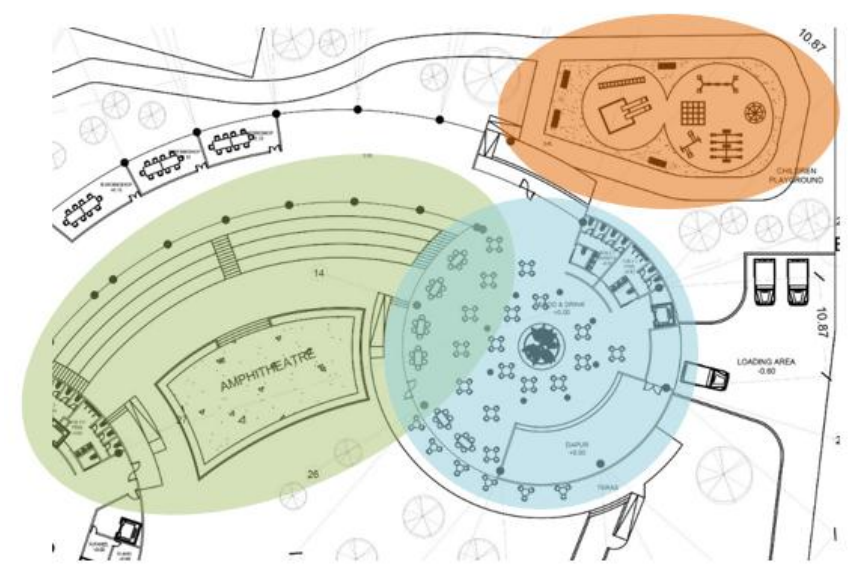

Gambar 23. Area Berkumpul

Sumber: dokumen pribadi, 2018

\section{Sarana Perdagangan Anggrek}

Diberikan fasilitas bagi para pedagang anggrek untuk menjajakan bunga-bunga yang dijual kepada para pengunjung. Tidak hanya pengunjung saja namun juga orang yang datang khusus untuk membeli anggrek dapat melihat-lihat variasi yang dijual. 


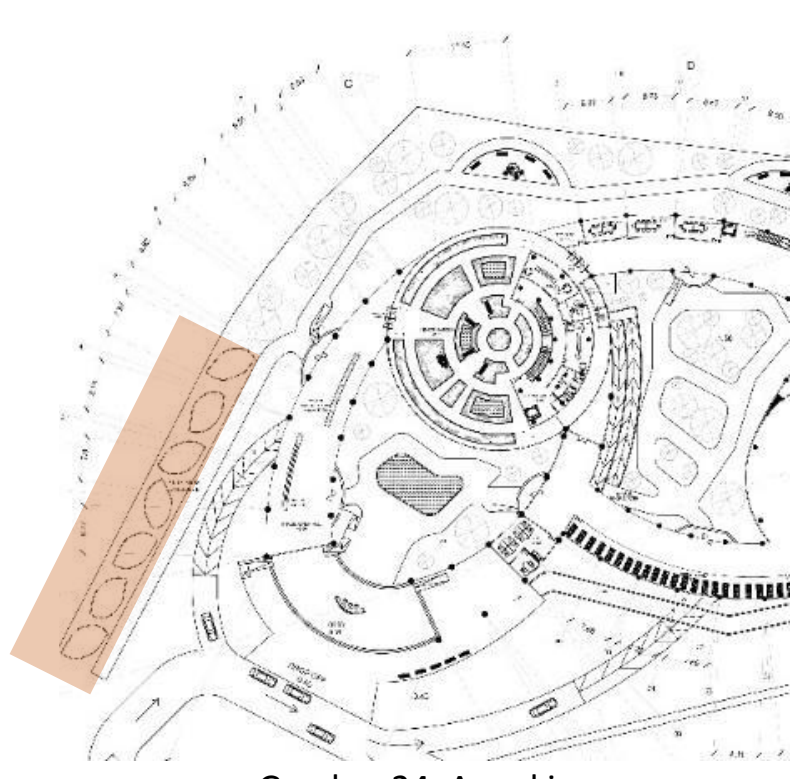

Gambar 24. Area kios

Sumber: dokumen pribadi, 2018

\section{KESIMPULAN DAN SARAN}

Architourism of The Metropolis merupakan pendekatan yang digunakan dalam penyelesaian masalah dan panduan perancangan dalam tugas Studio Perancangan Arsitektur 8.26 yang berfokus pada Taman Wisata dan Konservasi Anggrek Nusantara. Terdapat potensi di tapak terpilih yang dapat dijadikan sebagai daya tarik dari tempat wisata dalam kota metropolis.

Tidak berfungsinya kawasan Sentra Budidaya Anggrek dan Tanaman Hias di Kebon Jeruk merupakan sesuatu yang sangat disayangkan mengingat anggrek memiliki daya tarik yang kuat bagi masyarakat Indonesia bahkan mancanegara. Sejalan dengan topik pembahasan Architourism of The Metropolis ini diperlukannya pengetahuan mendalam mengenai potensi lokasi, masalah lokasi dan keterikatannya dengan sejarah dan edukasi sehingga potensi yang ada dapat dikembangkan dan masalah yang ada dapat dipecahkan sehingga proyek yang dibangun menjadi sebuah hal yang menarik bagi para wisatawan di kota metropolitan.

Secara singkat masalah yang ada di lokasi Sentra Budidaya Anggrek dan Tanaman Hias Kebon Jeruk adalah tidak berfungsinya kawasan sentra anggrek sebagaimana mustinya. Para petani anggrek dan pedagang anggrek yang dulunya beraktivitas di kawasan ini memilih untuk angkat kaki karena kawasan dijadikan pemukiman warga. Karena itulah kawasan ini tidak dapat berkembang walaupun titel sentra anggrek masih ditancapkan di kawasan.

Dengan prinsip Architourism of The Metropolis diberikan solusi berupa desain arsitektur yang menarik, dan memberikan wadah kembali bagi petani dan pedagang anggrek untuk beraktivitas dalam lingkup sentra anggrek yang hidup.

Untuk menghidupkan kembali kawasan sentra anggrek dibutuhkan data-data yang mendukung untuk memenuhi kebutuhan anggrek dan bagaimana membudidayakannya sehingga dapat memberikan edukasi pada pengunjung baik dari segi sejarah dan pengetahuan lainnya. Program mengutamakan kenyamanan pengunjung dalam mengeksplor anggrekanggrek nusantara yang ditanam secara ex-situ, dan pendistribusian edukasi yang menarik bagi pengunjung, juga bagaimana mengarahkan pengunjung untuk membeli anggrek yang dibudidayakan oleh petani lokal.

Dengan memperhatikan kebutuhan anggrek yang akan ditanam, maka dibutuhkan desain bangunan yang efisien dan mendukung tumbuh kembang bunga anggrek yang ditanam dengan cara ex-situ. Dengan menata dan mendesain alur perjalanan pengunjung di dalam bangunan dan taman, maka dapat diciptakan keadaan yang nyaman dan menarik sehingga kemungkinan pengunjung untuk datang lagi semakin tinggi.

Juga dengan mempertimbangkan alur dari masuk hingga keluar dapat diletakkan kios-kios 
pedagang anggrek secara tepat sehingga pengunjung akan datang menghampiri kios-kios yang ada. Dengan menyediakan sarana belajar untuk pengunjung secara interaktif dapat meningkatkan keinginan dan ketertarikan seseorang untuk belajar dan menggali ilmu tentang anggrek secara mudah dan menyenangkan.

Dengan memberikan solusi secara tepat sesuai potensi dan sejarah tapak maka dapat diciptakan sebuah proyek yang sejalan dengan tema Architourism of The Metropolis, dimana pengunjung dapat menikmati taman di tengah-tengah kota metropolitan dan pedagang dapat menjajakan barangnya dengan nyaman sehingga terjadi kesinambungan dalam proyek ini dan titel Sentra Budidaya Anggrek dapat disandang sesuai dengan kenyataan yang ada.

\section{UCAPAN TERIMA KASIH}

Terimakasih kepada para pedagang tanaman hias di kawasan Kebon Jeruk yang bersedia diwawancarai mengenai Sentra Budidaya Anggrek dan Tanaman Hias.

\section{REFERENSI}

BPS, Kota Administrasi Jakarta Barat. (2017). Kecamatan Kebon Jeruk Dalam Angka 2017. Jakarta. BPS.

Endersby, Jim. (2016). Orchid: A Cultural History. London. Kew Publishing.

Farrell, Patricia, Lundegren, Herberta M. 1983. The Process of Recreation Programming Theory and Technique. Venture Pub.

Raharja, K. (2014). Republika.com:

https://www.republika.co.id/berita/koran/urbana/14/10/29/ne6wk96-petani-anggrekmenyusut, diakses pada 10 Agustus 2018.

Specht, Jan. (2014). Architectural Tourism. Munich. Springer Gabler.

Vera, P. Erakini.com. https://erakini.com/jenis-bunga-anggrek/, diakses 24 Juli 2018. 